\title{
UNFAIR TRADING PRACTICES \\ IN THE AGRICULTURE AND FOOD SUPPLY CHAIN - COMPARING THE 2019/633 EU DIRECTIVE WITH THE HUNGARIAN REGULATION
}

\author{
MARTIN MILÁN CSIRSZKI*
}

\begin{abstract}
This brief summary is based on the author's presentation held on the 8th October 2020 on the international conference titled "Straf- und bußgeldrechtliche Verantwortung von Unternehmen insbesondere im Kartell- und Datenschutzrecht de lege lata und de lege ferenda" organised by the University of Heidelberg and the University of Miskolc. The study gives a short introduction to the comparison of the Directive (EU) 2019/633 on unfair trading practices in business-to-business relationships in the agricultural and food supply chain and the Hungarian regulation on the unfair practices of distributors.
\end{abstract}

Keywords: unfair trading practices, Hungarian regulation on unfair practices of distributors, EU Directive 2019/633, agriculture, food supply chain, comparison

The European Parliament and the Council adopted a new directive on unfair trading practices in business-to-business relationships in the agricultural and food supply chain in April 2019 (hereinafter referred to as 'the Directive'). ${ }^{1}$ The Directive follows a minimum harmonisation approach, so Member States may adopt or maintain national rules which go beyond the unfair trading practices listed in the Directive, which was preceded by a more than one decade-long period of preparation and negotiation. ${ }^{2}$ Superior bargaining power, economic dependence, dominance and

* PhD Student, Department of Agricultural and Labour Law, Faculty of Law, University of Miskolc.

1 Directive (EU) 2019/633 of the European Parliament and of the Council of 17 April 2019 on unfair trading practices in business-to-business relationships in the agricultural and food supply chain (OJ L 111., 25. 4. 2019, p. 59-72).

2 Hou, Liyang: Superior bargaining power: the good, the bad and the ugly. Asia Pacific Law Review, 27 (2019), 1, p. 46., https://doi.org/10.1080/10192557.2019.1661589. EU documents in connection with the topic: $\operatorname{COM(2009)} 591$ - Communication from the Commission to the European Parliament, the Council, the European Economic and Social Committee and the Committee of the Regions - A better functioning food supply chain in Europe; 2008/2175(INI) - Report on the Food prices in Europe; 2013/C 227 E/03 European Parliament resolution of 19 January 2012 on the imbalances in the food supply chain; COM/2013/037 - Green Paper on Unfair Trading Practices in the Business-toBusiness Food and Noon-food Supply Chain in Europe; COM(2014) 472 - Communication from the Commission to the European Parliament, the Council, the European Economic and Social Committee and the Committee of the Regions - Tackling unfair trading 
market concentration are all issues that can be heard of when speaking of competition in the agricultural and food supply chain. It is undoubtful that there are many existing problems coming from the globalisation of food systems. The most serious losses are faced by agricultural producers, small and medium-size enterprises who although fulfil a significant role in the food supply chain, but they experience severe challenges in their relationship with giant food processors and retail chains. ${ }^{3,4}$ As the Directive says: ,Within the agricultural and food supply chain, significant imbalances in bargaining power between suppliers and buyers of agricultural and food products are a common occurrence. Those imbalances in bargaining power are likely to lead to unfair trading practices when larger and more powerful trading partners seek to impose certain practices or contractual arrangements which are to their advantage in relation to a sales transaction." 5 This brief synopsis aims to provide some comparative aspects of the Directive and the Hungarian regulation in force, in particular the questions of scope rationae personae, scope rationae materiae, listed practices and sanction system. Before the merits, a few thoughts are presented regarding EU competition law, and after the comparison there are some statistical data of the Hungarian enforcement of the regulation. Finally, a conclusion is drawn up.

Competition law instruments of the European Union, i.e. the rules on the abuse of an undertaking of a dominant position (Article 102 TFEU) are not appropriate tools for handling this specific situation within the food supply chain. Although the market gets more and more concentrated, based on the market shares of food retailers the conditions required for the applicability of Article 102 TFEU are not fulfilled. ${ }^{6}$ Not only the EU rules, but also the national rules on the abuse of the dominant position are not suitable. ${ }^{7}$ Sui generis, specific norms are needed in order to handle the imbalances of the food supply chain. Until the adoption of the Directive,

practices in the business-to-business food supply chain; COM(2016) 32 - Report from the Commission to the European Parliament and the Council on unfair business-to-business trading practices in the food supply chain; 2018/C 086/05 - European Parliament resolution of 7 June 2016 on unfair trading practices in the food supply chain; $\operatorname{COM}(2018) 173$ - Proposal for a Directive of the European Parliament and of the Council on unfair trading practices in business-to-business relationships in the food supply chain.

3 ANDREe, Peter - AYRES, Jeffrey - Bosia, Michael - MASsiCotTE, Marie-Josee (eds.): Globalization and Food Sovereignty - Global and Local Change in the New Politics of Food. University of Toronto Press, Toronto, 2014, pp. 3-4.

4 SodAno, Valeria - VerneaU, Fabio: Competition Policy and Food Sector in the European Union, Journal of International Food \& Agribusiness Marketing, 26 (2014), 3, p. 162.

5 Directive, Preamble (1).

6 Daskalova, Victoria: The New Directive on Unfair Trading Practices in Food and EU Competition Law: Complementary or Divergent Normative Frameworks? Journal of European Competition Law \& Practice, 10 (2019), 5, p. 284.

7 In connection with the Hungarian regulation see FIRNIKSZ Judit - DÁVID Barbara: A versenyjog határterületei: a vevői erő régi és új szabályai. Magyar jog, 67 (2020), 5, pp. 276-287. 
no such regulation existed on EU level, but the member states have had different regulatory solutions on national level.

Twenty member states have some type of regulation in connection with unfair trading practices: there are 8 countries with cross-sector legislation: for example Germany. And there are 12 countries with specific legislative instruments applicable to the food supply chain. This group also includes Hungary. ${ }^{8}$

In Hungary, Act XCV of 2009 regulates the prohibition of unfair distributors' practices against suppliers concerning agricultural and food products (hereinafter referred to as 'the Act'). The Act came into force on 1st January 2010. We can see that the sector-specific UTP-regulation in Hungary has a past of more than then ten years without any regulatory obligation coming from the European Union. The title of the Act mentions distributors, but the scope ratione personae covers the relationship of producers, processors, and traders. The previous ones are natural persons producing or processing agricultural and food products (including primary producers, sole proprietors and family farmers), legal persons, organisations without legal personality, as well as producer organisations and producer groups. The latter ones, i.e. the traders (distributors) are natural persons, legal persons, organisations without legal personality who sell on agricultural and food products without transformation or processing, or who sell them to the final consumer, as well as third party operators providing services to such a person or organisation in connection with the purchase or sale of the product and in the course of this having a direct business relationship with the supplier of the product. There are no turnover thresholds, the scope ratione personae is not narrowed further. On the contrary, the Directive determines turnover thresholds regarding the scope ratione personae. It has to be mentioned that the Hungarian Act only prohibits the unfair trading practices of distributors (retailers) against suppliers. In contrary, the Directive covers the unfair trading practices of all actors in the food supply chain: not only of the distributors, but also of the wholesalers and processors against suppliers. As a consequence of these, we can say that the scope ratione personae of the Directive is narrower in one aspect, because the Hungarian Act does not differentiate according to turnover thresholds, but it is wider in another aspect, because the Directive not only covers the conduct of retailers contrary to the Act.

My opinion is that The Hungarian legislator will not and does not have to change the Act's scope ratione personae in connection with the turnover threshold determined by the Directive, but has to expand the protection of suppliers even against the wholesalers and processors. The reason for the previous one is the well-functioning enforcement mechanism of the Act, which should not be bothered by narrowing the scope regarding the turnover thresholds. Another reason is the following: if the suppliers with higher turnovers were excluded from the scope of the Act,

8 See in detail CAFAgGI, Fabrizio - IAMICELI, Paola: Unfair Trading Practices in the Business-to-Business Retail Supply Chain - An overview on EU Member States legislation and enforcement mechanisms. JRC Technical Reports, Luxembourg, Publications Office of the European Union, 2018. 
the regulation could get counter-productive, because the traders would rather purchase the products from the suppliers that does not fall within the scope of the Act. ${ }^{9}$

The scope ratione materiae is also different. The Hungarian Act refers to Article 2 of the regulation no. 178/2002 on laying down the general principles and requirements of food law, which says that 'food' (or 'foodstuff') means any substance or product, whether processed, partially processed or unprocessed, intended to be, or reasonably expected to be ingested by humans. To this definition the Act adds that those products fall under its scope ratione materiae that - in order to be sold to the final consumers - do not require further processing. According to the Directive, the scope covers agricultural and food products, which are products listed in Annex I to the TFEU as well as products not listed in that Annex, but processed for use as food using products listed in that Annex. There are several differences. I would like to mention two of them. For example, the Directive's scope covers all live animals, the Act's scope does not cover live animals, unless they are prepared for placing on the market for human consumption. The Directive's scope covers unmanufactured tobacco and tobacco refuse, although the Act's scope does not cover tobacco and tobacco products. In my opinion, the Hungarian legislator would have to change the Act's scope ratione materiae, in order for the Hungarian law to be in line with the Directive.

Nevertheless, we cannot forget that there is another act which regulates significant market power in Hungary: it is Act CLXIV of 2005 on Trade. It is a general act compared with the above-mentioned sector-specific act. According to this general act, the abuse of significant market power against the suppliers is forbidden; its scope covers all types of products that are the objects of sale between traders and suppliers, with the exception of the products covered by the sector-specific act. It is the conclusion of lex specialis derogat legi generali. The question arises: Is it appropriate that in order for the Hungarian law to comply with the Directive, two different Hungarian acts would include the rules of the Directive? The scope $r a$ tione materiae of the sector-specific act would cover the products already covered, but the scope ratione materiae of the general act would cover the new products that should be covered as a consequence of the rules of the Directive. In my opinion, it would not be a proper solution, therefore the modification of the sector-specific would be needed regarding its scope ratione materiae.

Concerning the most important part of the regulation, we can explore significant differences in connection with the list of unfair trading practices. In the Directive there are 15 practices listed: 9 of them are on the black list, so they are prohibited per se, 6 of them are on the grey list, which are prohibited, unless they have been previously agreed in clear and unambiguous terms in the supply agreement or in a subsequent agreement between the supplier and the buyer. The Hungarian Act does not apply a differentiation like this. If we look at the way of formulation of the Directive's and the Act's wording, we can conclude that the Directive is formulated in a much more general way than the Hungarian Act. The regulation of the latter

9 FIRNIKSZ: ibid. p. 277. 
one is casuistic, more detailed with its 28 different unfair distributors' practices. There are three listed practices in the Directive that cannot be corresponded to any of the unfair practices of the sector-specific Act. These are the following:

1. "the buyer unlawfully acquires, uses or discloses the trade secrets of the supplier within the meaning of Directive (EU) 2016/943 of the European Parliament and of the Council;

2. the buyer threatens to carry out, or carries out, acts of commercial retaliation against the supplier if the supplier exercises its contractual or legal rights, including by filing a complaint with enforcement authorities or by cooperating with enforcement authorities during an investigation;

3. the buyer requires compensation from the supplier for the cost of examining customer complaints relating to the sale of the supplier's products despite the absence of negligence or fault on the part of the supplier."

These practices shall be added to the Hungarian Act so that it can be in accordance with the Directive's minimum harmonisation approach. Although if we were permissive, a listed practice in the Hungarian Act may be appropriate for the third, above-mentioned practice. According to the Hungarian Act: it is unfair for distributors to require the use of services that are not requested by the supplier or that do not serve his/her interests, or to charge the supplier for these services based on any (legal) title. One of the elements of the second practice, 'the threatening' appears in a practice listed in the Hungarian Act, nevertheless the prohibition in the Hungarian regulation refers to cases where the different types of threats take place in order for the distributor could reduce the purchase price despite the protest of the supplier. In my opinion, all the other 12 practices listed in the Directive can be found in some form in the Hungarian Act, therefore only minor amendments are needed in the latter one.

Concerning the sanction system, the Directive says that the Member States shall ensure that each of their enforcement authorities has the necessary resources and expertise to perform its duties, and shall confer on it the power to impose, or initiate proceedings for the imposition of fines and other equally effective penalties and interim measures on the author of the infringement, in accordance with national rules and procedures. There are five other powers which are needed to be ensured for the enforcement authorities in favour of the efficient enforcement. ${ }^{10}$ The Member States can establish their own sanction system that is suitable for their legal traditions, i.e. different sanction systems can coexist next to each other in the Member States. Let us look at a few characteristics of the Hungarian Act's sanction system.

It can be divided into two parts: first, if the enforcement authority, i.e. the National Food Chain Safety Office (an administrative body) finds an infringement, it informs the trader before making a final decision that he can make a commitment statement within ten days to bring his conduct into line with the provisions of the law; second, if this does not happen, the enforcement authority imposes a fine. ${ }^{11}$

10 Directive, Article 6.

11 Act, 6. §. 
There are some cases where a fine is imposed without the possibility of submitting a commitment statement. ${ }^{12}$ During the examined nine years, 206 infringements took place on the basis of public data: the majority of these can be considered as violations of substantive law, which are covered by the Act, Section 3(2), and there are some cases of procedural violations, typically failure to provide information. With regard to the total number of cases, we can conclude that the procedures were closed with the imposition of a fine in about $70 \%$ of the cases, while a commitment statement was made in about the remaining $30 \%$ of the cases. The data show that judicial review proceedings have been initiated in respect of 45 administrative proceedings, representing approximately $22 \%$ of cases. If we look at the level of fines imposed, it is clear that 2011 and 2012 stand out, as more than one billion forints of fines were imposed in both years. In 2013, it fell to approximately HUF 215 million, and only year 2015 (HUF 224 million) and 2016 (HUF 227 million) could approach it. In 2014, a record low total amount of fine of HUF 6.5 million was imposed. Starting from 2017 (HUF 81 million), a slow increase can be observed, as both 2018 (HUF 108 million) and 2019 (HUF 166 million) exceeded the previous years.

All in all, there are some changes needed in order to implement the EU Directive appropriately, but we can say that the fundamentals of the Hungarian Act are adequate. The enforcement mechanism works with the predominant feature of applying financial sanctions, i.e. fines. The EU Directive is not going to bring significant transformation in the Hungarian sector-specific regulation of unfair trading practices in the agricultural and food supply chain.

\section{LIST OF LITERATURE}

[1] Andree, Peter - Ayres, Jeffrey - Bosia, Michael - MAssicotte, MarieJosee (eds.): Globalization and Food Sovereignty - Global and Local Change in the New Politics of Food. University of Toronto Press, Toronto, 2014.

[2] CAfaggi, Fabrizio - IAmiceli, Paola: Unfair Trading Practices in the Business-to-Business Retail Supply Chain - An overview on EU Member States legislation and enforcement mechanisms. JRC Technical Reports, Luxembourg, Publications Office of the European Union, 2018.

[3] Daskalova, Victoria: The New Directive on Unfair Trading Practices in Food and EU Competition Law: Complementary or Divergent Normative Frameworks? Journal of European Competition Law \& Practice, 10 (2019) 5., pp. 281-296.

[4] FIRNIKSZ, Judit - DÁVID, Barbara: A versenyjog határterületei: a vevői erő régi és új szabályai, Magyar jog, 67 (2020) 5., pp. 276-287.

12 Act, 8. § (1a). 
[5] Hou, Liyang: Superior bargaining power: the good, the bad and the ugly, Asia Pacific Law Review, 27 (2019) 1., p. 46.

https://doi.org/10.1080/10192557.2019.1661589.

[6] SODANO, Valeria - VERNEAU, Fabio: Competition Policy and Food Sector in the European Union. Journal of International Food \& Agribusiness Marketing, 26 (2014) 3., pp. 155-172. 